\title{
The role of mast cells, interleukin-13 and transient receptor potential channels in a mouse model of chemical-induced airway hyperresponsiveness
}

\author{
Fien Devos', Vanessa De Vooght, Benoit Nemery, Peter Hoet, Jeroen Vanoirbeek \\ From 9th Symposium of Experimental Rhinology and Immunology of the Nose (SERIN 2013) \\ Leuven, Belgium. 21-23 March 2013
}

\section{Background}

Occupational asthma is the most common work-related lung disease in industrialized countries. The mechanisms of occupational asthma caused by chemicals are still not completely understood. Therefore, we used a mouse model of chemical-induced asthma to examine the role of the neurogenic system as well as the role of IL-13 and mast cells by using different knock-out mice.

\section{Method}

On days 1 and 8 , wild type C57Bl/6 mice, IL-13, TRP (Transient Receptor Potential) A1, TRPV1 and mast cell deficient mice were dermally sensitized with $1 \%$ TDI (toluene-2.4-diisocyanate) or vehicle (acetone/olive oil) on both ears. On day 15, the mice received a single intranasal challenge with $0.1 \%$ TDI or vehicle. In a second experiment TDI or vehicle sensitized wild type $\mathrm{C} 57 \mathrm{Bl} / 6$ mice received an intraperitoneal injection of the NK1R antagonist RP67580 $(1 \mu \mathrm{g} / \mu \mathrm{l})$ prior to the challenge. Airway reactivity to methacholine, lung inflammation, lymphocyte subpopulations in the draining auricular lymph nodes and total serum IgE were assessed $24 \mathrm{~h}$ after the challenge.

\section{Results}

IL-13, TRPV1, TRPA1 and mast cell deficient mice showed a significant lower airway hyperreactivity compared to wild type mice, 24h after TDI challenge, without any sign of lung inflammation. Treatment with the NK1R antagonist also resulted in a significant decrease in airway

KU Leuven, Occupational, Environmental and Insurance Medicine, Leuven, Belgium

() Biomed Central hyperreactivity. In the auricular lymph nodes T-helper cells, T-cytotoxic cells and B-cells were significantly lower in mast cell deficient and IL-13 deficient mice, compared to wild type mice.

\section{Conclusion}

These results indicate the importance of IL-13, TRPA1 and TRPV1 channels and mast cells in the development of immune-mediated bronchial hyperreactivity.

Published: 16 July 2013

doi:10.1186/2045-7022-3-S2-P31

Cite this article as: Devos et al:: The role of mast cells, interleukin-13 and transient receptor potential channels in a mouse model of chemical-induced airway hyperresponsiveness. Clinical and Translational Allergy 2013 3(Suppl 2):P31.

Submit your next manuscript to BioMed Central and take full advantage of:

- Convenient online submission

- Thorough peer review

- No space constraints or color figure charges

- Immediate publication on acceptance

- Inclusion in PubMed, CAS, Scopus and Google Scholar

- Research which is freely available for redistribution 